\title{
Agro-climatic zoning of bamboo as a support for crop farming in the central-north region of the Brazilian Savannah ${ }^{1}$
}

\author{
Rafael Battisti², Derblai Casaroli², José Alves Júnior ${ }^{2}$, \\ Adão Wagner Pêgo Evangelista², Marcio Mesquita ${ }^{2}$
}

\section{ABSTRACT}

Bamboo has a huge potential for several uses; however, there are many species with numerous climatic growth requirements. This makes it difficult to characterize the agroclimatic bamboo demands, in order to define areas suitable for its cultivation. This study aimed to quantify the bamboo agroclimatic requirements, as well as to define areas suitable for growth in the central-north region of the Brazilian Savannah. The agro-climatic requirements were defined from averages of the center of origin of the Bambusa vulgaris species, in southwest Asia. The climatic characterization was based on the daily mean, minimum and maximum air temperature, annual rainfall and water deficit, and consecutive months with a rainfall rate lower than $40 \mathrm{~mm}$. These limits were used to define suitable, marginal and unsuitable regions. The optimal range was between $15.14{ }^{\circ} \mathrm{C}$ and $35.33{ }^{\circ} \mathrm{C}$ for mean air temperature, with a lower limit of $12.07^{\circ} \mathrm{C}$ and a higher limit of $38.83^{\circ} \mathrm{C}$, respectively, for minimum and maximum air temperature. The annual minimum rainfall required was $775 \mathrm{~mm}$, with a maximum annual water deficit of $1,320 \mathrm{~mm}$, and a maximum of eight consecutive months with rainfall of less than $40 \mathrm{~mm}$. Most of the studied region was classified as suitable ( $74 \%$ of the total area), followed by marginal due to water deficit (12.9\%), unsuitable (8.9\%) and marginal due to air temperature $(4.2 \%)$.

KEYWORDS: Bambusa vulgaris, climatic suitability, bamboo weather requirement, crop modeling, agrometeorology.

\section{INTRODUCTION}

Bamboo has been used for many purposes, such as construction and reinforcing fibers, paper and textiles, food and combustion, and other bioenergy applications. It is also ornamental (Scurlock et al. 2000). In addition, bamboo forests have a large capacity for carbon sequestration and play an important role in maintaining the regional ecological

\section{RESUMO}

Zoneamento agroclimático como subsídio para o cultivo de bambu no centro-norte do Cerrado brasileiro

O bambu possui grande potencial de uso em inúmeras finalidades; entretanto, as várias espécies apresentam diferentes demandas climáticas. Isto dificulta a caracterização das demandas agroclimáticas do bambu para definir áreas aptas ao seu cultivo. Objetivou-se quantificar as demandas agroclimáticas do bambo, bem como definir áreas aptas ao seu cultivo no centro-norte do Cerrado brasileiro. As demandas agroclimáticas foram definas a partir das médias do centro de origem da espécie Bambusa vulgaris, no sudoeste da Ásia. A caracterização climática baseouse na temperatura do ar diária média, mínima e máxima, chuva e déficit hídrico anual, e meses consecutivos com chuva abaixo de $40 \mathrm{~mm}$. Estes limites foram utilizados para classificar áreas aptas, marginais e inaptas. A temperatura média ótima variou entre $15,14^{\circ} \mathrm{C}$ e $35,33^{\circ} \mathrm{C}$. Já as temperaturas mínimas e máximas foram iguais a $12,07^{\circ} \mathrm{C}$ e $38,83^{\circ} \mathrm{C}$, respectivamente. A demanda anual mínima de chuva foi de $775 \mathrm{~mm}$, com déficit hídrico anual máximo igual a $1.320 \mathrm{~mm}$, e valor máximo de oito meses consecutivos com chuva menor que $40 \mathrm{~mm}$. A maior parte da região estudada foi classificada como apta (74 \% da área total), seguida por marginal por déficit hídrico $(12,9 \%)$, inapta $(8,9 \%)$ e marginal por temperatura do ar (4,2\%).

PALAVRAS-CHAVE: Bambusa vulgaris, adaptabilidade climática, exigência climática do bambu, modelagem de cultura, agrometeorologia.

environment and the global carbon balance (Zhou \& Jiang 2004, Mao et al. 2016).

There are around 75-90 genera and 1,1001,250 species of bamboo (Manhães 2008, Sanquetta et al. 2015). They occur naturally in all continents, except for Europe and Antarctica, in different climatic conditions (Scurlock et al. 2000). Bamboo forests are widely planted on hillsides and along roads in Japan, Malaysia, Brazil, Indonesia and Thailand, because

1. Received: May 02, 2018. Accepted: Aug. 20, 2018. Published: Feb. 06, 2019. DOI: 10.1590/1983-40632019v4952794.

2. Universidade Federal de Goiás, Escola de Agronomia, Goiânia, GO, Brasil.E-mail/ORCID: battisti@ufg.br/

0000-0001-5768-4501, derblaicasaroli@yahoo.com.br/0000-0001-8041-0066,josealvesufg@yahoo.com.br/ 0000-0002-1187-3275, awpego@gmail.com/0000-0002-6499-9306,marciomes@gmail.com/0000-0001-9399-4478. 
they have extensive root systems and underground rhizomes, which avoid landslides, as well as water and soil losses (Liese 2001, Li \& Kobayashi 2004, Zhou et al. 2005). The large number of bamboo species means a challenge to define adequate agroclimatic criteria for identifying areas where bamboo can be grown with a low climatic risk.

Climatic requirements may change considerably among bamboo species. Dendrocalamus asper is adapted to full sun and tolerates air temperatures of up to $-5^{\circ} \mathrm{C}$, while Bambusa multiplex tolerates growth under shadow environments and air temperature of up to $-10^{\circ} \mathrm{C}$ (Tombolato et al. 2012). As for annual rainfall, there is a huge requirement range recorded, from a lower limit of 700-1,200 mm year ${ }^{-1}$ (Rojas-Sandoval \& Acevedo-Rodriguez 2014, KFRI 2015) up to a maximum limit reaching 4,000 $\mathrm{mm}_{\text {year-1 }}$ (Scurlock et al. 2000, KFRI 2015).

When there are uncertainties regarding crop climatic requirements, an alternative is to characterize the climatic conditions at the center of origin, defining limits for crop growth, and then to apply to the region of interest. This approach was used for jatropha (Yamada \& Sentelhas 2014, Pena et al. 2016) and African mahogany (Casaroli et al. 2018), perennial plants, identifying agro-climatic requirements and delimiting suitable areas for growth in Brazil.

In Brazil, there are commercial areas of bamboo in the states of Maranhão and Pernambuco, growing the Bambusa vulgaris species (Manhães 2008). This species can be used for paper production and construction in the rural area (Tombolato et al. 2012). Bamboo has received many incentives to be included as an alternative in the farm system production, improving the farmers' profit due to its faster growth rates and multipurpose uses focusing on green biomass (Darabant et al. 2014).

Thus, bamboo has a high potential to be grown in the central-north region of the Brazilian Savannah, after identifying suitable areas, especially where traditional crops represent a high agro-climatic risk. Based on that, this study aimed to characterize the agro-climatic requirements of the center of origin of Bambusa vulgaris in southwest Asia, in order to define agro-climatic criteria for bamboo growth based on the probabilistic level of occurrence, as well as to classify the suitability of bamboo in the central-north region of the Brazilian Savannah biome, in Brazil.

\section{MATERIAL AND METHODS}

The bamboo agro-climate requirements were defined based on its center of origin, following the approach used for jatropha (Yamada \& Sentelhas 2014, Pena et al. 2016) and African mahogany (Casaroli et al. 2018), in Brazil.

Bambusa vulgaris has an uncertain origin, but evidences indicate southwest Asia, mainly south China, northeast India and Myanmar (Kleinhenz \& Midmore 2001, Tombolato et el. 2012). In India, bamboo is grown in the states of Arunachal Pradesh, Assam, Bihar, Madhya Pradesh, Manipur, Mizoram, Odisha, Tripura and West Bengal (KFRI 2015). The center of origin was selected including the states from India, Bangladesh and south of Nepal and Bhutan (Figure 1).

Gridded weather data were obtained from NASA POWER (2018), for the center of origin of Bambusa vulgaris, in a grid of $0.5 \times 0.5^{\circ}$ (Figure 1). The weather data were obtained daily from 01 January 1981 to 31 December 2017. Data included solar radiation, mean, maximum and minimum air temperature, rainfall, relative humidity and wind speed. The water deficit was estimated following the Thornthwaite \& Mather (1955) water balance approach, using $100 \mathrm{~mm}$ as soil water-holding capacity, and potential evapotranspiration was estimated by the Penman-Monteith method (Allen et al. 1998).

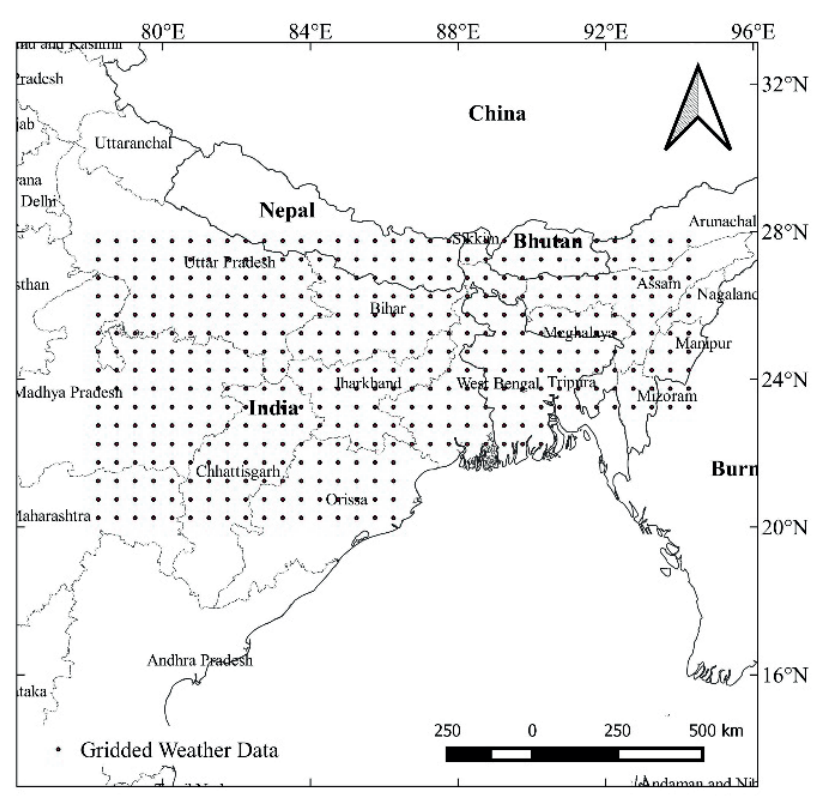

Figure 1. Location of the weather data (grid) at the center of origin of bamboo in southwest Asia. 
The bamboo agro-climatic requirements were obtained based on daily minimum, mean and maximum air temperature, annual accumulated rainfalls and water deficit, and consecutive months with rainfall of less than $40 \mathrm{~mm}$. The observed limits were defined for each location by eliminating $20 \%$ of weather data extremes. For daily mean air temperature, the interval of $10-90 \%$ was considered, and the limits for daily minimum and maximum air temperature were, respectively, $20 \%$ and $80 \%$. The limit for annual accumulated rainfall was $20 \%$, and, for accumulated water deficit and consecutive months with rainfall of less than $40 \mathrm{~mm}, 80 \%$. An example using these criteria for the gridded weather data point latitude $23.75^{\circ}$ and longitude $85.26^{\circ}$ is shown in Figure 2. Then, the final limits were defined
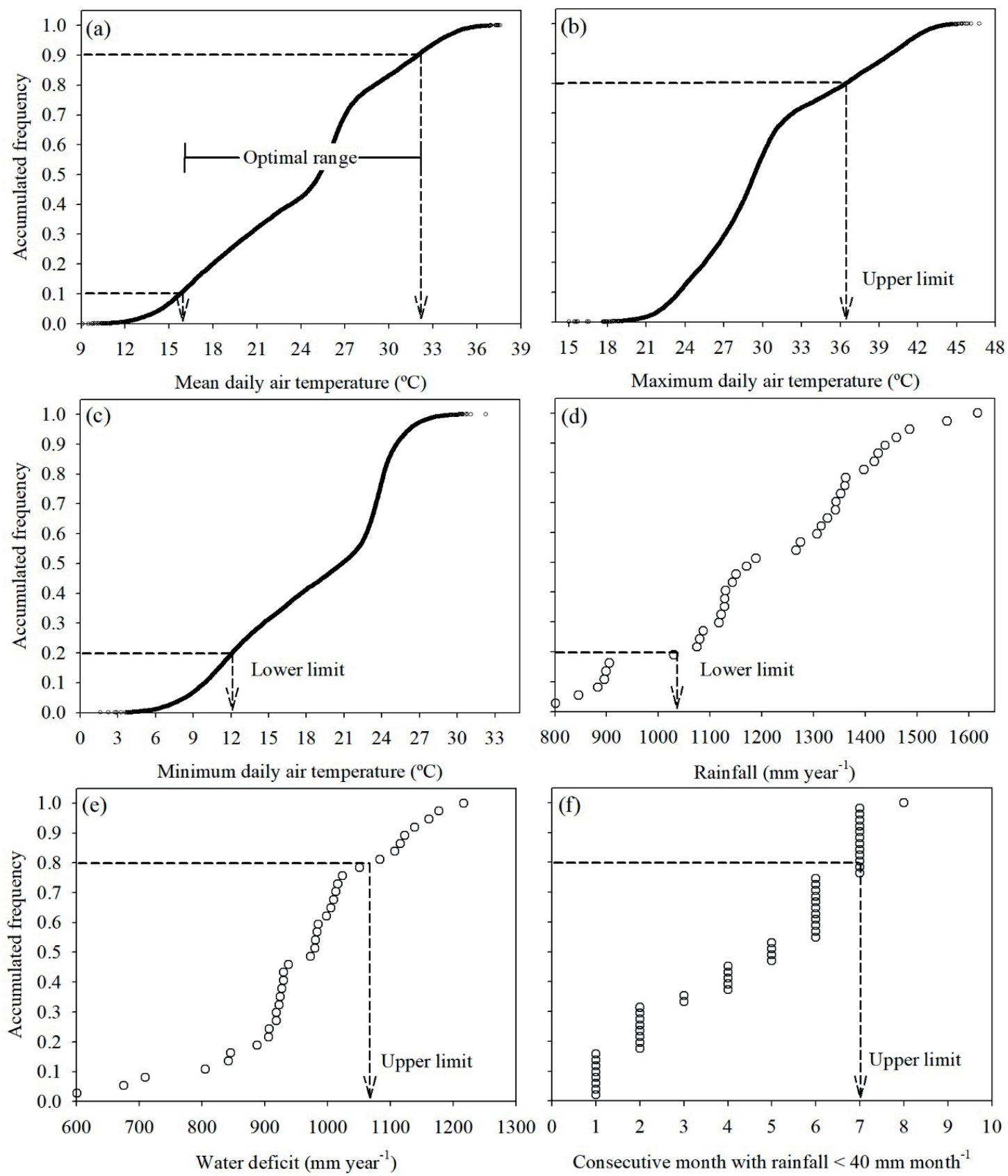

Figure 2. Agro-climatic limits for bamboo based on accumulated frequency of daily mean (a), maximum (b) and minimum (c) air temperature, annual accumulated rainfall (d) and water deficit (e), and consecutive months with rainfall of less than $40 \mathrm{~mm}$ (f) for the gridded weather data point latitude $23.75^{\circ}$ and longitude $85.26^{\circ}$. 
considering $70 \%$ of locations to represent the suitable area for bamboo growth.

The study area comprised the central-north region of the Brazilian Savannah biome, including the states of Goiás, Tocantins, Maranhão, west Bahia and south Piauí (Figure 3). That region has not only different climate conditions, but also a higher potential for the inclusion of bamboo in degraded areas and areas unsuitable for grain crops. In this region, the gridded weather data were obtained daily by Xavier et al. (2015), in a grid of $1.0 \times 1.0^{\circ}$ (Figure 3 ), for the period from 01 January 1980 to 31 December 2013, including the same variables aforementioned. The mean air temperature was obtained using the mean from maximum and minimum air temperatures for the gridded weather data.

The daily minimum, mean and maximum air temperatures, annual accumulated rainfalls and water deficit, and consecutive months with rainfall of less than $40 \mathrm{~mm}$ limits were used to define whether the weather location is suitable, marginal or unsuitable for bamboo growth. The point was suitable when all variable limits were within at least $95 \%$ of the weather series (days or years); marginal if variable limits were within at least $80 \%$ of the weather series; and unsuitable if one variable limit was outside $80 \%$ of the weather series. The marginal level was divided by air temperature (minimum, mean and maximum) or limitation of available water (annual accumulated

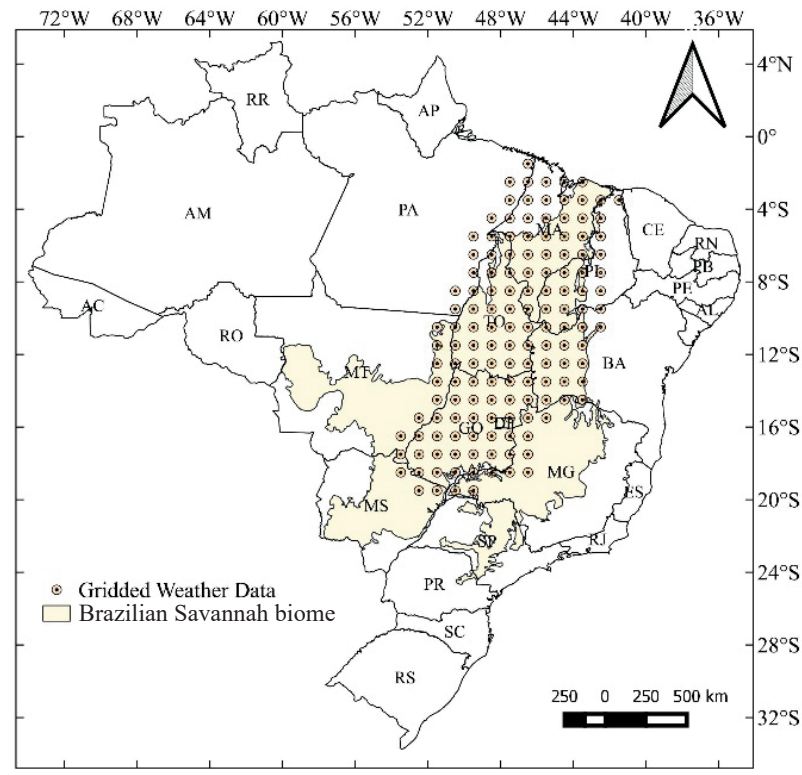

Figure 3. Location of the gridded weather data for the agroclimatic zoning of bamboo in Brazil. rainfalls and water deficit, and consecutive months with rainfall of less than $40 \mathrm{~mm}$ ).

The spatial suitability (suitable, marginal and unsuitable) was determined considering the classification and the linear interpolation between neighbor weather points. The county was classified based on the predominant suitability for agro-climatic zoning in the area, defined by weather points in their surroundings. The final map was plotted using the QGIS v. 3.01 software (QGIS Development Team 2018), classifying the county suitability into suitable, marginal due to air temperature, marginal due to water availability or unsuitable.

\section{RESULTS AND DISCUSSION}

The agro-climatic limits obtained for daily mean air temperature had an optimal range between $15.15^{\circ} \mathrm{C}$ and $35.33^{\circ} \mathrm{C}$ (Table 1), based on the center of origin of bamboo in southwest Asia. The lower limit for minimum and the upper limit for maximum air temperatures were, respectively, $12.07{ }^{\circ} \mathrm{C}$ and $38.82{ }^{\circ} \mathrm{C}$ (Table 1). These limits were close to the range observed for favorable net photosynthetic rates based on leaf temperature for bamboo (Bambusa ventricosa). The maximum net photosynthetic rates occurred within the range of $21.8-30.6^{\circ} \mathrm{C}$, reducing to the half its maximum value when the leaf temperature was below $16.2{ }^{\circ} \mathrm{C}$ and above $36.3{ }^{\circ} \mathrm{C}$ (Gratani et al. 2008).

The center of origin of bamboo had a lower annual rainfall of $775 \mathrm{~mm}^{\text {year }}{ }^{-1}$, limited to a maximum annual water deficit of $1,320 \mathrm{~mm} \mathrm{year}^{-1}$, and a maximum of eight consecutive months with rainfall of less than $40 \mathrm{~mm}$ (Table 1). Scurlock et al. (2000) described that some bamboo species can adapt to varying environments, but most need warm and humid conditions, with a mean annual temperature of at least $15-20{ }^{\circ} \mathrm{C}$ and rainfall above $1,000 \mathrm{~mm}$ year $^{-1}$. There was no consensus as for the annual rainfall volume required by bamboo. There was a demand of 700 mm year $^{-1}$ (Rojas-Sandoval \& Acevedo-Rodriguez 2014 ) to $4,000 \mathrm{~mm}$ year $^{-1}$ (Scurlock et al. 2000). The range can be associated with the potential crop evapotranspiration, in function of local climatic conditions.

The agro-climatic limits were similar to the values reported in the literature, although discrepancies can be found due to the definition of conditions for crop presence or high biomass 
Table 1. Criteria and limits obtained for bamboo growth based on the center of origin.

\begin{tabular}{llc}
\hline \multicolumn{1}{c}{ Agro-climatic variables } & \multicolumn{2}{c}{ Description } \\
\hline & \multicolumn{2}{c}{ Air temperature $\left({ }^{\circ} \mathrm{C}\right)$} \\
\cline { 2 - 3 } Mean & Optimal range & $15.14-35.33$ \\
Minimum & Lower limit & 12.07 \\
Maximum & Upper limit & 38.82 \\
\cline { 2 - 3 } & & Water \\
Annual rainfall & Lower limit & 775 mm year $^{-1}$ \\
Annual water deficit & Upper limit & 1,320 mm year $^{-1}$ \\
Consecutive month with rainfall $<40 \mathrm{~mm} \mathrm{month}^{-1}$ & Upper limit & 8 months $^{2}$ \\
\hline
\end{tabular}

production. The Bamboo Technical Support Group South Zone, from the Kerala Forest Research Institute (KFRI 2015), indicated that bamboo requires an optimal temperature range of $20-38^{\circ} \mathrm{C}$ for a maximum growth, with a mean annual temperature ranging between $8{ }^{\circ} \mathrm{C}$ and $36^{\circ} \mathrm{C}$. The annual rainfall requirement reported was $900-4,000 \mathrm{~mm}$ year $^{-1}$, higher than that defined in our study (Table 1). Such different levels of climatic adaptability can define the final biomass production, which may vary from $4.5 \mathrm{t} \mathrm{ha}^{-1}$ year ${ }^{-1}$ to $47 \mathrm{t} \mathrm{ha}^{-1}$ year ${ }^{-1}$ for aboveground biomass, respectively for central China and southern India (fertilized and irrigated areas) (Scurlock et al. 2000), in function of agro-climatic conditions.

Rojas-Sandoval \& Acevedo-Rodriguez (2014) reported a broader range for optimal climatic conditions for bamboo growth. The mean annual air temperature ranged between $15{ }^{\circ} \mathrm{C}$ and $40{ }^{\circ} \mathrm{C}$, values similar to those observed at the center of origin (Table 1). The mean maximum temperature of the hottest month (maximum of $50{ }^{\circ} \mathrm{C}$, higher than observed at the center of origin) and the mean minimum temperature of the coldest month (minimum of $10^{\circ} \mathrm{C}$ ) were close to those analyzed in this study (Table 1). The authors reported that the absolute minimum temperature had a lower limit of $-3{ }^{\circ} \mathrm{C}$. For rainfall, the limits indicated by RojasSandoval \& Acevedo-Rodriguez (2014) were similar to those of the center of origin, i.e., $700 \mathrm{~mm}$ year ${ }^{-1}$ against $775 \mathrm{~mm}_{\text {year }}{ }^{-1}$. In both cases, the maximum of eight consecutive months with a rainfall of less than $40 \mathrm{~mm}$ month $^{-1}$ was established as the limit.

Based on previous agro-climatic criteria (Table 1), the central-north region of the Brazilian Savannah was classified into four suitability types. The main area suitable for bamboo growth included most of the Goiás, Tocantins and Maranhão states (Figure 4), where all limits from Table 1 occurred for more than $95 \%$ of the analyzed period. This showed the potential of bamboo growth along the centralnorth region of the Brazilian Savannah. This higher suitability can be verified by the presence of more than 230 species of bamboo in Brazil (Tombolato et al. 2012).

The southwest of the Goiás state was classified as marginal, because it reached the low air temperature limit: for more than $5 \%$ of the days, the minimum air temperature was below $12.07^{\circ} \mathrm{C}$. In this region, the agro-climatic zoning for jatropha was classified as suitable, attending the optimal range for annual mean air temperature $\left(23-27^{\circ} \mathrm{C}\right)$ (Yamada \& Sentelhas 2014). For African mahogany, the classification was

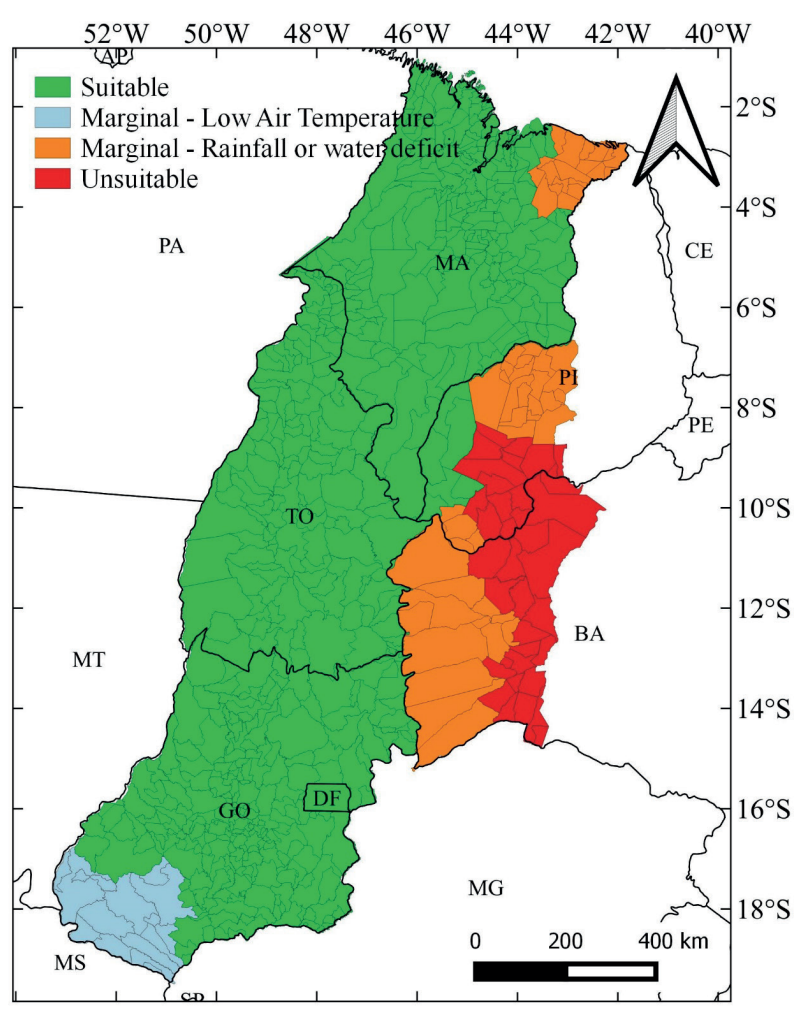

Figure 4. Agro-climatic zoning for bamboo (Bambusa vulgaris) in the central-north region of the Brazilian Savannah. 
suitable, but with a restriction due to the mean annual air temperature below $23.5^{\circ} \mathrm{C}$ (Casaroli et al. 2018). In addition to the differences in crop limits, density, distribution and source of weather stations along the region may affect the areas of suitability transition (Xavier et al. 2015, Mourtzinis et al. 2017, Battisti et al. 2018).

The extreme west of the Bahia state, the center of Piauí and the northeast of Maranhão were classified as marginal, due to the low water availability along the year (Figure 4). In this area, the minimum annual rainfall and/or maximum annual water deficit were attended for, at least, $80 \%$ of the years studied. Otherwise, the classification was unsuitable due to water unavailability from this area up to near the border of the semiarid of the northeast Brazil (Figure 4). In this unsuitable area, other perennial crops can be grown instead of bamboo; however, with restrictions. In this region, the area was classified as marginal for jatropha due to water deficit (Yamada \& Sentelhas 2014), while African mahogany was classified as suitable, but with a medium restriction (Casaroli et al. 2018). Eucalyptus had a high, mean and low climatic adaptation, depending on the species (Flores et al. 2016).

The central-north region of the Brazilian Savannah had $74 \%$ of the area classified as suitable for bamboo growth (Table 2). The low air temperature leads to a marginal suitability in $4.2 \%$ of the area, condition that could not limit the bamboo growth, except for its maximum annual growth (Scurlock et al. 2000). The lower air temperature occurs during the dry season of the Brazilian Savannah biome (Brasil 2018), helping to reduce the crop evapotranspiration and stress by water deficit on crop growth (Piouceau et al. 2014, Mei et al. 2016).

The marginal area (due to water limitation) covered $12.9 \%$ of the total area (Table 2). In this area, other bamboo species can be used instead

Table 2. Classes of agro-climatic suitability for bamboo (Bambusa vulgaris) in the central-north region of the Brazilian Savannah.

\begin{tabular}{lc}
\hline \multicolumn{1}{c}{ Suitability } & Percentage of the regions \\
\hline Suitable & 74.0 \\
Marginal - air temperature & 4.2 \\
Marginal - water & 12.9 \\
Unsuitable & 8.9 \\
\hline Total & 100.0 \\
\hline
\end{tabular}

of B. vulgaris. Sanquetta et al. (2015) highlighted that the $B$. oldhammii species has a higher drought tolerance than $B$. vulgaris, which can be used for food and woody peaks. Further analysis is required to understand how bamboo adapts during the dry period, such as leaf area reduction, and to determine the biomass production volume, which correlates with evapotranspiration (Piouceau et al. 2014). Finally, the unsuitable area represented $8.9 \%$ of the analyzed area, where bamboo growth had a high risk of low water availability, which limits crop planting and biomass production.

\section{CONCLUSION}

The agro-climatic zoning indicated most of the central-north region of the Brazilian Savannah as suitable for growing the Bambusa vulgaris species (74 \% of the total area), followed by marginal due to water deficit $(12.9 \%)$, unsuitable $(8.9 \%)$ and marginal due to air temperature (4.2\%).

\section{REFERENCES}

ALLEN, G. R. et al. Crop evapotranspiration: guidelines for computing crop water requirements. Rome: FAO, 1998. (Irrigation and drainage paper, 56).

BATTISTI, R.; BENDER, F. D.; SENTELHAS, P. C. Assessment of different gridded weather data for soybean yield simulations in Brazil. Theoretical and Applied Climatology. 2018. Available at: $<$ https://doi.org/10.1007/ s00704-018-2383-y>. Access on: 21 Mar. 2018.

BRASIL. Instituto Nacional de Meteorologia. Normais climatológicas. 2018. Available at: <http://www.inmet. gov.br/portal/index.php?r=clima/normaisClimatologicas $>$. Access on: 09 Apr. 2018.

CASAROLI, D. et al. Edaphoclimatic aptitude to African mahogany in Brazil. Ciência Florestal, v. 28, n. 1, p. 357368, 2018.

DARABANT, A. et al. Bamboo biomass yield and feedstock characteristics of energy plantations in Thailand. Energy Procedia, v. 59, n. 1, p. 134-141, 2014.

FLORES, T. B. et al. Eucalyptus no Brasil: zoneamento climático e guia para identificação. Piracicaba: IPEF, 2016.

GRATANI, L. et al. Growth pattern and photosynthetic activity of different bamboo species growing in the Botanical Garden of Rome. Flora, v. 203, n. 1, p. 77-840, 2008. 
KERALA FOREST RESEARCH INSTITUTE (KFRI). Manual for establishment and management of bamboo plantations. Peechi: Bamboo Technical Support Group South Zone, 2015.

KLEINHENZ, V.; MIDMORE, D. J. Aspects of bamboo agronomy. Advances in Agronomy, v. 74, n. 1, p. 99-149, 2001.

LI, Z.; KOBAYASHI, M. Plantation future of bamboo in China. Journal of Forestry Research, v. 15, n. 3, p. 233242, 2004.

LIESE, W. Advances in bamboo research. Journal of the Nanjing Forestry University, v. 25, n. 4, p. 1-6, 2001.

MANHÃES, A. P. Caracterização da cadeia produtiva do bambu no Brasil: abordagem preliminar. 2008. $32 \mathrm{f}$. Monografia (Curso de Engenharia Florestal) - Universidade Federal Rural do Rio de Janeiro, Seropédica, 2008.

MAO, F. J. et al. Development of the BIOME-BGC model for the simulation of managed Moso bamboo forest ecosystems. Journal of Environmental Management, v. 172, n. 1, p. 29-39, 2016.

MEI, T. et al. Water use patterns of four tropical bamboo species assessed with sap flux measurements. Frontiers in Plant Science, v. 6, n. 1, p. 1-12, 2016.

MOURTZINIS, S. et al. From grid to field: assessing quality of gridded weather data for agricultural applications. European Journal of Agronomy, v. 82, n. 1, p. 163-172, 2017.

NASA POWER. Power data access viewer v1.0.7 beta. 2018. Available at: $<$ https://power.larc.nasa.gov/dataaccess-viewer/>. Access on: 01 Mar. 2018.

PENA, D. S. et al. Agroclimatic zoning for jatropha crop (Jatropha curcas L.) in the state of Goiás. Acta Scientiarum, v. 38, n. 3, p. 329-335, 2016.

PIOUCEAU, J. et al. Actual evapotranspiration and crop coefficients for five species of three-year-old bamboo plants under a tropical climate. Agricultural and Water Management, v. 137, n. 1, p. 15-22, 2014.

QGIS DEVELOPMENT TEAM. QGIS geographic information system. Version 3.0.1. 2018. Available at: $<$ http://qgis.osgeo.org>. Access on: 10 Jan. 2018.

ROJAS-SANDOVAL, J.; ACEVEDO-RODRIGUEZ, P. Bambusa vulgaris (common bamboo). 2014. Available at: < https://www.cabi.org/isc/datasheet/8398>. Access on: 09 Apr. 2018.

SANQUETTA, C. R. et al. Biomassa individual de Bambusa oldhamii Munro e Bambusa vulgaris Schrad. ex. J.C. Wendl. Cerne, v. 21, n. 1, p. 151-159, 2015.

SCURLOCK, J. M. O.; DAYTON, D. C.; HAMES, B. Bamboo: an overlooked biomass resource? Biomass and Bioenergy, v. 19, n. 4, p. 229-244, 2000.

THORNTHWAITE, C. W.; MATHER, J. R. The water balance. New Jersey: Drexel Institute of Technology, 1955.

TOMBOLATO, A. F. C.; GRECO, T. M.; PINTO, M. $\mathrm{M}$. Ten species of more common exotic bamboos in the landscape in Brazil. Revista Brasileira de Horticultura Ornamental, v. 12, n. 2, p. 104-114, 2012.

XAVIER, A. C.; KING, C. W.; SCANLON, B. R. Daily gridded meteorological variables in Brazil (1980-2013). International Journal of Climatology, v. 36, n. 6, p. 26442659, 2015.

YAMADA, E. S. M.; SENTELHAS, P. C. Agro-climatic zoning of Jatropha curcas as subside for crop planning and implementation in Brazil. International Journal of Biometeorology, v. 58, n. 9, p. 1995-2010, 2014.

ZHOU, G. et al. Ecological functions of bamboo forest: research and application. Journal of Forestry Research, v. 16, n. 2, p. 143-147, 2005.

ZHOU, G.; JIANG, P. Density, storage and spatial distribution of carbon in Phyllostachys pubescens forest. Scientia Silvae Sinicae, v. 40, n. 6, p. 20-24, 2004. 